International Journal of Linguistics, Literature and Translation

ISSN: 2617-0299 (Online); ISSN: 2708-0099 (Print)

DOI: $10.32996 / \mathrm{ijlt}$

Journal Homepage: www.al-kindipublisher.com/index.php/ijllt

\title{
Complying and Coping: A Phenomenological Analysis of the Lived Experiences of College Students Studying During the COVID-19 Outbreak Lockdown
}

\author{
Regina Chriscel S. Delute ${ }^{18}$ (D) $\square$ and Jhune Carlo S. Ada ${ }^{2}$ (D) \\ ${ }^{12}$ MA Ed, College of Teacher Education, Batangas State University, Batangas City, Philippines \\ $\triangle$ Corresponding Author: Regina Chriscel S. Delute, E-mail: reginachriscel.delute@g.batstate-u.edu.ph
}

\section{ARTICLE INFORMATION}

Received: February 11, 2021

Accepted: March 04, 2021

Volume: 4

Issue: 3

DOI: $10.32996 /$ ijllt.2021.4.3.21

\section{KEYWORDS}

COVID-19, remote education, remote teaching, phenomenological research

\section{ABSTRACT}

The COVID-19 outbreak resulted in the sudden shift from on-campus class to remote learning using different ways, but mainly through the use of the internet to deliver instruction and submit the requirements. While the news is full of statistics about the COVID-19 cases, recoveries, and deaths, not much has been written about the plight of students during the pandemic. This study looked into the lived experiences of the five education students enrolled in Batangas State University learning on their own at home during the time of the Luzonwide lockdown in the Philippines. This phenomenological research utilized voice calls (Messenger) in getting data from the participants. In analyzing the data, the researchers identified the frequent words or phrases, categorized the responses, then identified the themes. Four themes emerged from the interviews: students partook in asynchronous learning for grades; remote education during a pandemic affords students' stress and anxiety; students prefer inface classes over distance learning; and they have insufficient technology. The study concluded with the understanding that the sudden implementation of distance learning, the student-participants view this mode of learning as a means to comply and to cope with the set standards given the available measures and resources. The student-participants are able to experience the truly independent and individual manner of learning. Participants need to adjust to the new mode of learning, for they are still in the traditional face to face mode of delivery of learning and education and Resources and means to connect are the major concerns of students especially those in the remote areas both the region and nearby provinces.

\section{Introduction}

Education is both a gift and a basic right in the Philippines. It is the present that catapults children to different careers. As one of the chief rights of Filipino children, it is made accessible to the youth (The Child and Youth Welfare Code). Education offers the advantage to be one step closer to one's ambitions and dreams. It starts when a child aged five or six is enrolled as a first-grader in an elementary school and attends for six years then moves on to high school. Through Republic Act 10533 or the Enhanced Basic Education Act, high school education has an additional two years. The law called for implementing the $\mathrm{K}$ to $12 \mathrm{Curriculum}$ in the Philippines. This reform allows the graduates to find work after finishing high school. Others who desire to pursue higher education can enroll in colleges and state universities.

Higher Education Institutions (HEI) all over the country offer degree programs and certifications. Under the Commission on Higher Education (CHED), HEls cater to the needs of the students by ensuring that they get quality education. Students attend their classes and listen as their instructors or professors explain the lessons. Teachers utilize technology like televisions, speakers, personal computers, and projectors to deliver important concepts to their students. This kind of setup where students and teachers regularly see each other in class is known as face-to-face instruction. Hirko and Ross (2004) stated that this type of learning has many advantages and chief of these is human contact. Students get first-hand experience of the learnings by doing

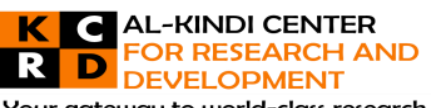

Your gateway to world-class research

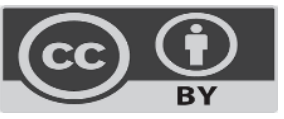

Published by Al-Kindi Center for Research and Development, United Kingdom. Copyright (c) the author(s). This open access article is distributed under a Creative Commons Attribution (CC-BY) 4.0 license 
classroom activities through personal interactions such as brainstorming sessions, role-playing, and group games. They also get immediate help from their classmates and on-the-spot feedback from the teachers.

This changed when, on March 16, 2020, the whole island of Luzon was placed under community quarantine due to the outbreak of COVID-19. This consequently led to the cancellation of classes. For days, the students and teachers in HEls waited and wondered about what would happen to their unfinished semester. Student governments from the top four universities i.e. University of the Philippines, Ateneo De Manila University, De La Salle University, and the University of Santo Tomas filed a petition to CHED to stop online classes due to the pandemic (Bagayas, 2020). However, the CHED declared on April 14 that colleges and universities are allowed to adjust their academic calendars (Magsambol, 2020). This authorized the HEls using the new academic calendar to extend the semester to a maximum of one month after the enhanced community quarantine (ECQ) is lifted. For schools using the old academic calendar, they were allowed to end their school year (CNN Philippines, 2020).

Given the authority to continue the semester, instructors and professors were faced with the challenge of delivering instruction to their students using whatever means possible. On the part of the students, the shift from in-face classes to remote education is sudden and bracing themselves for the new normal in education could lead to stress and anxiety. While news about the developments and decisions of HEls and CHED are abundant, there is little research related to the lived experiences of college students participating in remote learning while the COVID-19 pandemic is plaguing the country. This paper addresses that gap by highlighting the experiences of the college students. Therefore, this research will add to the knowledge base of college students' information and their remote education experiences during a virus outbreak. Specifically, this research wants to find out the answers to these sub-questions: 1 . What are the reasons for participating in distance learning; 2 . How did the participants describe their distance learning experience; 3 . What are the benefits of distance learning during a pandemic; and 4. What are the drawbacks or barriers of distance learning?

To provide clarity and understanding about this research, the response of the government, particularly the Commission on Higher Education, on COVID-19 and Distance Learning are briefly discussed.

\subsection{COVID-19 in the Philippines}

Most countries in the world have suffered from the coronavirus disease known as the COVID-19. According to the World Health Organization (2020), it is a new strain of the coronavirus and is very infectious. Starting from Wuhan in China, the virus has spread like wildfire to other countries. It has been transmitted through respiratory droplets and contact routes leading to community lockdowns and travel bans (WHO, 2020).

The first confirmed case of COVID-19 in the Philippines is a Chinese woman from Wuhan. This confirmation came from the Department of Health (DOH) Secretary, Mr. Francisco Duque III. The Secretary disclosed that the patient had no fever, which meant that she was asymptomatic and did not have other signs and symptoms except for the mild cough (ABS-CBN, 2020). On February 2, France-Presse (2020) reported that the Philippines had recorded its first death of a COVID-19 patient outside of China although said patient had been stable for days. It was a numbers game from February to March as the DOH continued recording the number of those who contracted the disease, those who recovered, and those who died. Due to the increasing number of suspected cases of the disease, President Rodrigo Duterte ordered a Luzonwide enhanced community quarantine (ECQ) or total lockdown (Merez, 2020). This order paved the way for stricter implementation of quarantine policies such as the closing of establishments like malls and restaurants, no transportation, and the utilization of the one-quarantine pass per household.

The virus outbreak has affected tourism in the Philippines, its economy, and, of course, its education. Since the second week of March, schools in Metro Manila have been closed after the President suspended classes (Casas and Araja, 2020) due to the rising number of confirmed cases. Graduation ceremonies were also not allowed since the mass gathering was prohibited. In this scenario, schools that had yet to finish their academic year have resulted in conducting online classes.

\subsection{Distance Education}

The Philippines is one of the countries hit hard by the COVID-19. Not only is the economy threatened but also education. Since the enhanced community quarantine (ECQ) last March, the education sector has also jumped to distance education known as distance learning.

Simonson et al. (2015) explained that distance education is "institution based, formal education where the learning group is separated, and where interactive telecommunications systems are used to connect learners, resources, and instructors." Based on this definition, The Association of Educational Communications and Technology, as cited by the authors, explained four 
components of distance education. First of these is the idea that distance education is based on an institution. This proves that distance education is different from self-study. Simonson et al. (2015) explained that although institutions can be schools of universities, they could also be from the business sector. Another component is the distance between the teacher and the students. Distance is discussed in the authors' work as the physical (geographical) separation, difference of time, and intellectual separation of the teacher and the learners.

The third component is the interactive telecommunication. The authors elaborated that even though interaction is important and can be done synchronously and asynchronously, it is not the chief feature of instruction. Imparting content is still the aim but interaction must be made available, commonplace, and relevant. Sharing of learning experiences is the last concept. The authors explained that resources should connect students and teachers. Resources must undergo the steps for instructional design to organize into learning experiences that promote learning.

In her article, Brown (2015) said that distance learning has four advantages. These are flexibility of learning whenever and wherever the students are, no commuting since learning takes place online, significant cost savings since students do not have to rent houses near the campus and they can save on food, and convenient learning since learners can learn at their own pace.

As cited in UNESCO's discussion paper in 2002, open learning and distance education represent approaches that focus on opening access to education and training provision, freeing learners from the constraints of time and place, and offering flexible learning opportunities to individuals and groups of learners. It is further emphasized that open and distance learning is one of the most rapidly growing fields of education, and its potential impact on all education delivery systems has been greatly accentuated through the development of Internet-based information technologies, and in particular the internet.

\section{Methodology}

This research is qualitative in design. Creswell $(2013$, p. 44) mentioned that qualitative research starts with an assumption and the use of a theoretical framework. He added that the product of this type of research includes the voices of the participants and involves more paying more attention to the interpretive nature of inquiry. He also stated that the study must be within the researcher's context, may it be social, political or cultural. Creswell said that qualitative researches must empower people by letting their voices be heard.

Creswell (2012) claimed that qualitative research is suitable if there is scarcity of literature. Because not too much literature about remote learning during a virus outbreak exists, one must derive data from the participants who have lived the said phenomenon. With college students enduring the demands of their course load mixed with the blend of the COVID-19 crisis, a qualitative take would result in rich data describing the tertiary students' lived experiences.

Since lived experiences are vital in this study, phenomenology was used. As a qualitative approach, phenomenological research concentrates on understanding the essence of the experience by describing the lived phenomenon (Creswell, 2019, p. 19). Specifically, the phenomenological approach utilized here is the transcendental, focusing on the participants' stories. This approach, based on Moustakas' model (1994) has four steps: the epoche in which the researcher recognizes her biases and then writes them down. The next step is known as the phenomenological reduction, which allows the investigator to consider the idea that there is always more to events than what is originally perceived. Imaginative variation, the third step, lets the researcher collect stories and experiences from the participants and then, finally, turning this collection into themes (Creswell, 2007, p.60).

\subsection{Participants and Setting}

To be able to participate in this study, certain criteria must be met. First, participants must be English major students in their sophomore year enrolled in the course Mythology and Folklore. This was purposive because these learners have been the researcher's students since freshman year, and they have experienced the flipped and blended learning strategies in the courses which she taught. Due to ethical concerns, participants must be over 18 years old and willing to participate in the study. Third, participants must have done course assignments at home during the enhanced community quarantine (lockdown). Finally, due to safety protocols and compliance to the Inter-Agency Task Force (IATF) guidelines, in order to be selected, participants must have a good internet connection since the only way the research could gather data is through chat and voice calls using the Messenger app. Thus, the 12 participants were identified.

\subsection{Procedure}

To obtain the12 college students' lived experiences, two men and 10 women, this qualitative research used phenomenological inquiry. As Bogdan and Biklen (2003, p. 23) explained, by using this approach, the researcher will attempt to understand the meaning of events and interactions to ordinary people's situations. The goal is to capture the second-year English major students' personal experiences involved in distance learning. 
Following Moustakas (1994), the researcher first wrote down her lived experiences as a teacher of courses taught using the blended learning and flipped approach and her experiences of no face-to-face classes that began on March 16, 2020. Next, the participants were selected based on already established standards that fits the research. The researcher began recruiting the students that would later participate by posting a letter in their class FB Group. The letter introduced the purpose of the study, the descriptions and the procedures that the students would undergo once they are recruited. Additionally, the letter contained a confidentiality clause and the risk and benefits that they would get. The students were assured that no risk would befall them once they chose to participate. The letter also informed them that once they consent to be participants, they would be included in a group chat which would be used for voice call. The purpose of the voice call in Messenger was to review everything stated in the letter and solicit the time for their availability for a phone interview since the students could not go to school because of the lockdown.

Five students met the criteria to become participants. They were sent the list of the four overarching questions and were informed that there might be follow up questions depending on their responses. The follow up questions aided the researcher in extracting more information from the participants. After the participant answered the voice call, the researcher informed them that she would record the stories digitally and give them a transcription of everything they said during the interview. The four questions were used as a guide to prompt the participants to share their experiences as distance learners in a pandemic time. Finally, the researcher sent a thank you note to all five participants.

\subsection{Data analysis}

Moustakas' (1994) model was utilized in analyzing the phenomenological data including the researchers'. All statements were recorded and transcribed verbatim. By so doing, the researcher was able to list all utterances pertinent to the experiences of the participants. Next, the researcher went through the data and took note of the statements that were deemed significant in giving light to the participants' experience. After this, the utterances were categorized into themes. These were then used in writing the description of what the experience was about.

\section{Findings and Discussion}

Table 1. Profile of the Participants

\begin{tabular}{|c|c|c|c|c|}
\hline Participant & Codename & Age & Residence & $\begin{array}{c}\text { Years of } \\
\text { Attending } \\
\text { Blended } \\
\text { Learning/ } \\
\text { Flipped } \\
\text { Classroom }\end{array}$ \\
\hline 1 & Athena & 20 & $\begin{array}{c}\text { Kumintang Ilaya, } \\
\text { Batangas City }\end{array}$ & 3 \\
\hline 2 & Thalia & 20 & $\begin{array}{c}\text { Sta. Rita Aplaya, } \\
\text { Batangas City }\end{array}$ & 4 \\
\hline 3 & Lexus & 20 & Tingloy, Batangas & 2 \\
\hline 4 & Justin & 20 & Cuta, Batangas City & 4 \\
\hline 5 & Artemis & 20 & Tulo, Batangas City & 2 \\
\hline
\end{tabular}

All research participants are 20-year old, second year college students taking up Bachelor of Secondary Education major in English. Participant 1 with codename Athena lives in Kumintang Ilaya, Batangas City with her family. She has participated in blended learning and flipped classrooms for three years. The next participant chose the codename Thalia. She is a resident of Sta. Rita Aplaya, has a four-year experience of being a student of teachers who hold blended learning and flipped classrooms. Participant 4, with codename Zeus, has the same number of years of attending such classes. Justin Lives in Cuta, one of the barangays in the said city with confirmed cases of COVID-19.

Meanwhile, both Artemis and Lexus have experienced being students of blended learning and flipped classroom teaching for two years. Artemis lives in Tulo, located in Batangas City, while Lexus resided in Tingloy which can be reached using a small boat. 
From the responses of the participants, three (3) categories emerged. These are student engagement, course requirements, and required technology. From these three come the four themes i.e. 1. Students partake in asynchronous learning for grades; 2. Remote education during a pandemic affords to students to improve themselves while learning; 3 . Students prefer in-face classes over distance learning; and 4. Students have insufficient technology.

The following part addresses each sub-question. Each narrative is followed by a follow up explanation and a related idea coming from other authors or researchers.

Theme 1. Students partake in asynchronous learning for grades.

The participants shared their lived experiences and their study process during the lockdown. It was found out that there are two sub-themes for the first theme.

\section{Compliance}

All participants shared that they participated in distance learning mainly to comply with the requirements. They told the researcher that they understood the importance of finishing their course work and given tasks. All five of them believed that finishing the semester was important. One of them, Thalia, used strong words while detailing her reasons. Consequently, the researcher got a solid sense of frustration.

"It was mandatory, and we have no choice. This mode of teaching does not have a pure quality like the formal teaching. We have no choice but to adapt to finish the sem(ester)."

Thalia added that she would not have participated if she were not aiming for better grades than previous semester. Artemis, another participant, also shared that compliance was the only way to catch up with lessons:

"The reason I participated was because it was the only way that we could learn our lessons during this pandemic. We were halfway through the semester, but we did not get to take our midterms due to class suspensions. I needed to see the course assignments and learn on my own so that I could submit my assignments."

Moreover, it is evident that the five participants understood that they had to do their academic tasks to get grades. Since they were on a lockdown and were not allowed to go out, they resorted to relying on the internet to get word of what their class was tasked to do and to submit their outputs online. Distance learning offered them the chance to learn on their own, at their own pace. Brown (2017) called this flexibility. Based on the participants' responses, it is apparent that distance education was helpful to them during the lockdown.

\section{Coping Strategy}

Interestingly, participants stated that they participated in their asynchronous classes because they wanted to cope with what was happening around them With the order for the Luzonwide lockdown since March, they were experiencing some anxiety and felt that the COVID-19 outbreak in the Philippines had robbed them of physical classes. Thus, for these students, participating in distance learning was their strategy to have that sense of normalcy in an unusual situation. Lexus said:

"For now, because the ECQ (enhanced community quarantine) hasn't been lifted, we see the importance of remote learning. All the news ever talks about is the pandemic. It is nice to still have that interaction with classmates and teachers during this time."

Brown (2017) mentioned that one of the disadvantages of distance learning is the lack of social interaction. For Lexus, that is not the case. Through distance learning, he was able to maintain the interaction with his teachers or classmates, albeit limited because he lives in Tingloy where blackout is normal at 10 pm every night till morning. He revealed that he tried to forget the dismal dilemma that the news reported by actively participating in his class discussion board and doing his assignments.

\section{Theme 2. Remote education during a pandemic affords to students' stress and anxiety.}

\section{Difficult}

Distance learning as the Philippine education trend is the response of most HEls. For some, this is a good idea but for the participants, they found their experience of this kind of setup difficult. Lexus elucidated that he had trouble adapting because of the sudden migration of classes completely on Facebook Groups and Google Classrooms. 
"It's hard when there is no teacher. I have to understand everything on my own. My mind is all over the place right now. With the virus outbreak and taking care of my mother who is amputated, studying at home adds more confusion to my mental health."

Kumar (2015) coined this as an adaptability struggle. He explained that the transition from traditional classroom situation to computer-based teaching makes it more difficult for students to learn. Lexus had pointed out that he was confused. This only meant that he could not concentrate on his course assignments. Another participant also found distance learning problematic during a community quarantine when people are limited to their home spaces. For Thalia, her home's comfort was not an ideal place to study since her siblings were there and there were household chores to accomplish.

Thalia elaborated that her siblings were bickering while she tried to focus on her academic work. It was hard for her to grasp the concepts of her lessons because it was noisy. She added that she was overwhelmed with the requirements to be submitted. Meanwhile, Justin described his experience of distance learning stressful. As he said:

"I felt I was being paranoid. What goes in my mind while studying are those which I see

in the news.

Instead of focusing on the learning tasks, she, just like Lexus, dealt with chores well. Household work, siblings playing and running around were just some of the distractions while the participants were studying. According to Brown (2017), students doing distance learning would find difficulty tracking their course work without face-to-face interactions with teachers and peers. As evidenced by the participants' responses, distraction was one of the things they dealt with during their sudden homeschooling.

\section{Theme 3. Students prefer in-face classes over distance learning.}

Participants also revealed that they still favor and opt to be inside the four walls of a classroom learning together with their instructor and classmates. Being in school for more than 15 years, there seems to be a sudden need to adapt in the mode of learning independently. In addition, the pressure of managing household tasks, keeping their families safe from the virus, and doing tasks at home also adds to the demand to focus on learning. Students still preferred the in-face classes over the distance learning mode with the presence of these concerns.

\section{Limited impact to students}

The participants also pointed that learning via distance is not as impactful as the face to face one. For the students, the transfer of learning seems to lack the direct conveyance of information as well the validation and clarification that happen when both the teachers and students interact on the subject matter. This notion roots from the nature of distance learning that does not require real time presence of both. Students are provided with instant feedback in the face to face set up that can justify or clarify their thoughts at once. This is explicitly cited by Justinwho stated that:

"I think it is a bit lacking since there is no physical interaction between instructors and learners."

This coincides with Tamayao's (2013) discussion that formal education normally takes place within the four walls of the classroom with the teachers, guided by a set of organized activities. This is the set-up or process that the participants have been exposed and educated since their preparatory years. The sudden change in mode of delivery made them think that the level of learning is not as effective as when the instructors are with them.

According to Justin For me (him), it's a bit ineffective because most of the time, students learn more when they are taught directly, or there is a face to face interaction between teachers and learners.

For him, the presence of the teacher has a direct effect on how students learn. This posits that direct teaching is seen to be more effective by the students than indirect methods like in the form of distance learning.

\section{Social learning over independent learning.}

The same is experienced and perceived by Athena. Meeting classmates face-to-face is more effective as she prefers to be physically present while interacting with others in the classroom. She focused on highlighting the role of socialization in learning.

We as a social being are used to day-to-day interaction. Maybe not all, but most of us want to be out there, at school, learn from the teachers as well. I think this type of education will not be as effective as the usual classroom set up, where we are able to do group activities with our classmates, learn together and share ideas together.

This mode of delivery is seen to be less effective by Athena compared to the traditional mode or set up in the classroom. She also posits that collaborative learning via distance learning is not felt as well. There are instances that students are able to create 
better insights as they share their individual thoughts. The feedback, in addition, given by the teacher also adds conviction to the ideas generated by the students making them feel that they are learning.

Artemis also expressed "Honestly, remote learning compared to the usual classroom setup that we had was hard during the first few days since it was kind of like an adjustment period for us. Nonetheless, we were able to cope with the new setup. I don't really think remote learning is easier than our usual classroom setup because there are a lot of factors to consider in order to participate in classes this way (e.g., internet service, means to communicate like phone or laptop, and time since we do not have a concrete schedule). If I would choose between the two, I'll still pick the usual classroom set-up which uses the blended-learning approach."

Though there is mention of blended learning, the term centers on the viability and presence of the three important elements: the teacher, students and the content that comes in varying forms. These are all present in the usual setup experienced by the students. Despite being able to adjust, she mentioned that she would still prefer the in-face environment rather than the distance mode of delivery.

\section{Theme 4. Students have insufficient technology.}

The participants highlighted that distance learning is for those who have gadgets and access to the internet. The limited tools and gadgets hindered the students in providing the best output or performance. Since the pandemic caused the abrupt suspension of classes in all levels, the participants are subject to the reality of facing the

\section{Digital divide}

With the tools, materials and resources becoming digital and electronic in format, there are experiences that placed the participants at a disadvantaged situation. There is an evident lack of these among the students like Athena. According to her, "The drawbacks and barriers that I have experienced with the remote learning/alternative mode of teaching and learning setup is the unstable internet connection, the slower system of my gadgets and my eyes are blurring because of staring and doing my activities too long in front of my computer."

Considering that the participants do not have the same resources, their participation and access level also differs looking into tools and connectivity aspects. These critical aspects are crucial in the successful completion of tasks given to students. Students are limited by these realities with regard to access to remote learning notwithstanding the effects on health and physique that can be caused by prolonged exposure to the technology. With Athena's experience, vision is the one directly affected by such.

On the other hand, Thalia expressed that the implementation of distance learning is not appropriate and applicable to students. She emphasized students who are from the lower class of the society. For these students, they would rather prioritize the essentials over the expenses needed to have access to the internet and available gadgets as well. Thalia stated that:

"Well it is not suitable for all students, especially those in the lower class who do not have the proper access to the trend in education nowadays."

As cited by Tamayao (2013), one of the challenges to be addressed is digital divide. There is an evident need for training between the teachers and students caused by the disparity between the skills and gadgets of the teachers compared to what the students have.

\section{Weak means to connect.}

Another drawback cited by the respondents is the poor and the lack of connection in the internet. Since most of the students do not have subscription to internet service providers or data providers at home. This posited additional costs for the prepaid load to be registered to limited data subscription or promo.

This is made evident by the experiences of Artemis who cited that "The only drawback that I experience/noticed is the lack of good internet service. This new mode of teaching is good, it is the country who is not really prepared for this kind of new teaching method."

This is similar to the experience of Justinron who had a problem with regard to network coverage and signal. In addition, Thalia also pointed out this concern for she also experienced internet connection problems coinciding with the need to have better and smarter gadgets.

According to Thalia "Well it is not suitable for all students, especially those in the lower class who do not have the proper access to the trend in education nowadays."

Geographical locations and topography where students live also contributed to the difficulties encountered by the participants. There are areas in the region and nearby provinces that have poor signal resulting in weak connectivity via data. By the virtue of 
Executive Order No. 112, the strict quarantine measures also added to the hindrance of moving from one place to another to look at a place with a strong network signal. According to this and with the implementation of enhanced community quarantine, people shall stay at home and are mandated to limit movement from one place to another except for essential purposes.

\section{Distance learning entails more expenses}

Connection to the internet in the country requires money and additional expenses. Since the students cannot go to the University that provides free internet, participants need to ensure and secure connection to the internet. However, this required the students to spend additional loading expenses, especially those who do not have a wired internet connection. More pressing is that some families need to prioritize expenses for the food and other utilities on top of the economic lag due to no work policy especially those who are self employed. This is highlighted by Lexus who mentioned that:

"There are big changes. First, the free wifi of the University is gone. Next, loading up is a hard task."

As mentioned by Artemis: "The only drawback that I experience/noticed is the lack of good internet service". The drawback mentioned here quality of internet connection is one of the main concerns on top of the price. This high price does not always equate to quality internet service.

As reported by Ordinario (2017), the bad internet connection is a more pressing problem in the country compared to poverty and corruption, as stated in the release of the Philippine Institute for Development Studies (PIDS). It is cited that mobile cellular services and fixed broadband services are priced at $\$ 22.24$ (second highest) and $\$ 51.59$ per month (third highest), respectively, based on data from the International Telecommunication Union. Despite the high costs, the Philippines's average connection speed was only at 2.8 Megabits per second (Mbps) for the third quarter of 2015.This is significantly lower than the global average connection speed of $5.1 \mathrm{Mbps}$ and the second slowest in the Asia-Pacific region. As emphasized in the study, the price, nevertheless, does not translate to quality service. Despite the high cost, the Philippines' Internet speed is among the slowest in the Asia-Pacific region. With the pressing concern cited in the report, the need for reloading and subscribing to data providers require students to spend additional money to make them connected and be able to connect to available online and/or digital platforms.

\section{Conclusion}

In light of the lived experiences of the participants in this analysis, the following are the conclusions drawn.

1. With the sudden implementation of distance learning, the student-participants view this mode of learning as a means to comply and to cope with the set standards given the available measures and resources.

2. The student-participants can experience the truly independent and individual manner of learning.

3. Participants need to adjust to the new mode of learning for they are still in the traditional face to face mode of delivery of learning and education

4. Resources and means to connect are the major concerns of students especially those in the remote areas both the region and nearby provinces.

\subsection{Recommendations}

Based on the findings and conclusions, the following are hereby recommended.

1. Practicality and relevance to real life experiences shall be evident in the learning tasks given to students.

2. Gradual transition from modular type to online/digital mode of distance learning shall be implemented.

3. Videos or learning activities with teachers as the source and guide to the learning process shall be provided and included in the given tasks.

4. Proper profiling of students as well as their resources shall be done to ensure maximum participation among students.

\section{Acknowledgment}

The researchers would like to thank the five participants that willingly shared their experiences while doing their remote education. Their stories served as the inputs crucial in understanding the lives of students whose studies have been affected by the school shutdown. 


\section{References}

[1] Brown, E. (2017, July 21). Advantages and Disadvantages of Distance Learning. Retrieved from https://www.eztalks.com/elearning/advantages-and-disadvantages-of-distance-learning.html

[2] Casas, W.; Araja, Rio (March 10, 2020). "Duterte suspends classes in Metro Manila Until March 14". Retrieved March $30,2020$.

[3] Coronavirus disease (COVID-19) in the Philippines. (n.d.). Retrieved May 17, 2020, from https://www.who.int/philippines/emergencies/covid-19-in-the-philippines

[4] "Coronavirus: What we know about first death outside China". Rappler. Agence France-Presse. February 2, 2020. Retrieved March 29, 2020.

[5] Creswell, J. W. (2012). Educational research: Planning, conducting, and evaluating quantitative and qualitative research (4th ed.), Boston, MA: Pearson

[6] Division of Higher Education, UNESCO. (2002). Open and distance learning trends, policy and strategy considerations. Retrieved May 15, 2020 from https://unesdoc.unesco.org/ark:/48223/pf0000128463.

[7] Executive Order No. 112. Retrieved May 15, 2020 from https://www.officialgazette.gov.ph/2020/04/30/executive- order-no-112-s2020/retrieved uploaded on: May 1, 2020 by Presidential Communications Operations Office (PCOO)

[8] France-Presse, A. (2020, February 7). Coronavirus: What we know about first death outside China. Retrieved from https://www.rappler.com/nation/250815-coronavirus-what-we-know-about-first-death-outside-china

[9] Kumar, S. (2015, July 10). 5 Common Problems Faced By Students In eLearning And How To Overcome Them. Retrieved from https://elearningindustry.com/5-common-problems-faced-by-students-in-elearning-overcome

[10] Merez, Arianne (March 16, 2020). "Luzon under enhanced community quarantine as COVID-19 cases rise". ABS-CBN News. Retrieved March 17, 2020.

[11] Modes of transmission of virus causing COVID-19: implications for IPC precaution recommendations. (2020, March 29). Retrieved April 6, 2020, from https://www.who.int/news-room/commentaries/detail/modes-of-transmission-of-virus-causing-covid-19-implications-for-ipcprecaution-recommendations

[12] Oliveira, Mayra \& Penedo, Antonio \& Pereira, Vinícius. (2018). Distance education: advantages and disadvantages of the point of view of education and society. Dialogia. 139-152. 10.5585/dialogia.N29.7661.

[13] Ordinario, C. "For Filipinos, poor Internet connection a more bothersome issue than poverty, corruption." Business Mirror. April 17, 2017https://businessmirror.com.ph/2017/04/17/for-filipinos-poor-internet-connection-a-more-bothersome-issue-than-povertycorruption/

[14] https://news.abs-cbn.com/news/01/30/20/philippines-confirms-first-case-of-new-coronavirus

[15] Simonson, M., Smaldino, S., \& Susan, Z. (2015). Teaching and Learning at a Distance : Foundation of Distance Education (6th ed.). Charlotte, North Carolina: Information Age Publishing Inc.

[16] Tamayao, A. I. (2013). Social dimensions of education (first edition), Manila, Philippines: Rex Bookstore 